"TO SARTABA, FROM SARTABA"

\title{
A NEW PROPOSAL TO IDENTIFY THE LOCATION OF THE SECOND STATION ON THE BEACON LINE FROM JERUSALEM TO BABYLON
}

\author{
MITIA FRUMIN \\ Hadassah Academic College, Jerusalem, e-mail: mitiaf@gmail.com
}

Received: $16^{\text {th }}$ June 2017, Accepted: $26^{\text {th }}$ December 2017

\begin{abstract}
AbSTRAKT
The Hebrew calendar is a lunisolar calendar. Its months are based on the revolution of the moon about the Earth, as it is said: This is the burnt offering of every new moon throughout the months of the year ${ }^{1}$ (Num. 28:14)

At the present time the moment of the true new moon is approximated mathematically. However during the Second Temple period, the beginning of the new lunar month had to be observed and certified by witnesses. Then the Sanhedrin Court was to make a public proclamation on the first day of the lunar month (ראש חודש).

In Mishnah, Tractate Rosh Hashana, Chapter 2 describes the process of communicating the information about the beginning of new month through the chain of beacon fires:

"From the Mount of Olives to Sartaba, and from Sartaba to Grofina, and from Grofina to Hauran, and from Hauran to Bet Biltin. From Bet Biltin they did not move, but rather waved back and forth and up and down until he saw the whole of the diaspora before him lit up like one bonfire." 2

Questioning of reliability of the quoted above description, its completeness and exclusiveness of the delineated in the Mishnah route is beyond the scope of the presented research. In this article we'll apply methods of the geographic information systems (GIS) analysis in order to examine the existed theories regarding localization of Sartaba - the second mentioned station in the chain of beacon fires, reveal their discrepancies and propose an innovative, albeit rather technical, solution for long-known problem.
\end{abstract}

Keywords: Sartaba, Mishnah, visibility analysis, GIS

\section{FORMULATION OF PROBLEM}

In general two approaches to understanding of the Mishnah defined account could be distinguished. It could be understood literally - as Sartaba is the station next to one on the 
Frumin M.: To Sartaba, from Sartaba" a new proposal to identify the location of the second station on the beacon line from Jerusalem to Babylon

Mount of Olives ${ }^{3}$. In this case there are no intermediate posts between these two sites and the signal is transferred directly by eye contact. Therefore two beacon fire stations should visible to each other, or more specifically, at least Mount of Olives beacon fire should be seen from Sartaba. This is a prevailing approach in research today. Hereinafter this theory will be referenced as "Direct".

Since $19^{\text {th }}$ century most researchers ${ }^{4}$ agree that said Sartaba was located at the top of the Horn of Sartaba ${ }^{5}$ mountain peak in the Jordan Valley, where excavations revealed remains of Hasmonean established stronghold, fortress Alexandrion. However numerous repeated tests proved that it is impossible to see from there the Mount of Olives or any other high mountain in vicinity of Jerusalem. In order to resolve the contradiction, several hypotheses were suggested in the past. The most common among them is an assumption that in the past one of the fortress elevated towers, non-preserved today, did serve as a beacon station (hereinafter: Direct - CisJrd).

In 1982, Meir Ben-Dov proposed an alternate identification of Sartaba ${ }^{6}$ across the Jordan Valley on its eastern side in mounting area of the Tobiads' realm, not far from present day Iraq al-Amir (hereinafter: Direct-TransJrd). This proposition was highly criticized ${ }^{7}$ mostly due to problematic suggestions that led Ben-Dov to his conclusions. However either Ben-Dov himself, neither his critics didn't deepen into actual examination of visibility issues, limiting discussion mostly by historical and etymological subjects.

Another method suggests that the list of stations is not complete and consequently there were other non-mentioned in Mishnah interim beacon fire stations (at least one) between Jerusalem and Sartaba. Hereinafter this theory will be referenced as "In-between".

A series of experiments were designed in order to examine both Direct and In-between concepts.

\section{BASICS OF VISIBILITY ANALYSIS}

Visibility analysis experiments were designed for and conducted by using ESRI ArcGIS software standard 3D Analyst Toolbox. This extension allows determining which locations of digital terrain model (DTM) raster surface are visible to chosen observer. Oppositely, it is also possible to identify which observer points are visible from each raster surface locations (Viewshed Tool). It is possible also to determine the visibility of sight lines over obstructions consisting of a surface (Line of Sight tool)

The visibility of each cell center is determined by comparing the altitude angle to the cell center with the altitude angle to the local horizon. The local horizon is computed by considering the intervening terrain between the point of observation and the current cell center. If the point lies above the local horizon, it is considered visible.

In order to gain more control over the visibility analysis process several parameters could be modified. One of them is Offset parameter. There are two offset items, one defining the

\footnotetext{
${ }^{3}$ See clarifications as regards to identification of the mentioned in the original text "Mount of Mishkha" - הר המשחה as Mount of Olives in the "Primary assumptions and experiments design" section

${ }^{4}$ Robinson, 1857: 293-294; Conder \& Kitchener, 1882: 396-401; Obermeyer, 1929: 17, 21; Abel, 1933: 124; Tsafrir \& Magen, 1984

${ }^{5}$ New Israel Grid: 243756 x 667033, 377 m

${ }^{6}$ Ben-Dov, 1982

${ }^{7}$ Irsai, 1982
} 
elevation to be added to the observer location and the other defining what will be added to each cell to be considered for visibility (Fig. 1).

Fig. 1: OFFSET parameters

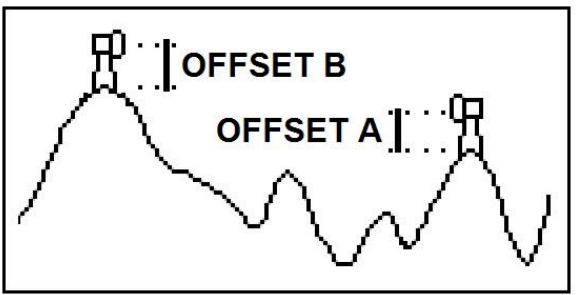

The OFFSETA item indicates a vertical distance in surface units to be added to the z-value of the observation point. The OFFSETB item indicates a vertical distance in surface units to be added to the z-value of each cell as it is considered for visibility.

\section{Digital TerRain MODEL}

The DTM is raster dataset in which an elevation value (in our case - height) is attributed to each square cell of the grid. The entire cell area is assumed to have the same value. Apparently as smaller cell size is, accuracy of analysis is higher (Fig. 2).

\section{Fig. 2: DTM structure}

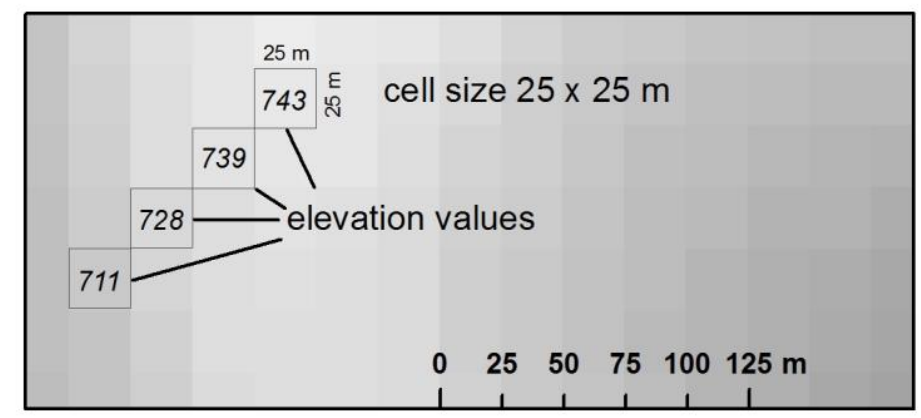

For Direct - CisJrd experiments John K. Hall's 25-m DTM of Israel ${ }^{8}$ was used. However site of Sartaba suggested by Meir Ben-Dov situates beyond the limits of the 25-m DTM of Israel. Therefore for Direct-TransJrd experiments an additional DTM was used with slightly different, but nevertheless still comparable resolution. This was N31E035 dataset from NASA Shuttle Radar Topography Mission Global 1 arc project ${ }^{9}$. Parameters of utilized DTM raster surface are provided in the Table 1 .

\footnotetext{
${ }^{8}$ Hall, 2008

9 The Shuttle Radar Topography Mission (SRTM) datasets result from a collaborative effort by the National Aeronautics and Space Administration (NASA) and the National Geospatial-Intelligence Agency (NGA - previously known as the National Imagery and Mapping Agency, or NIMA), as well
} 
Frumin M.: To Sartaba, from Sartaba" a new proposal to identify the location of the second station on the beacon line from Jerusalem to Babylon

Table 1: DTM used for visibility analysis

\begin{tabular}{|c|c|c|c|}
\hline DTM & Provided by & Cell size & Experiments \\
\hline $25-\mathrm{m}$ DTM of Israel & GSI $^{10}$ & $25 \mathrm{~m} \times 25 \mathrm{~m}$ & Direct - CisJrd \\
\hline N31E035(SRTM) & NASA & $\sim 30 \mathrm{~m} \times 30 \mathrm{~m}$ & Direct - TransJrd \\
\hline
\end{tabular}

\section{PRIMARY ASSUMPTIONS AND EXPERIMENTS DESIGN}

The first mentioned in Mishnah station is called Mount of Mishkha - הר המשחה which is universally assumed to be one of the summits of Mount of Olives. This identification is based on several additional references from both Old ${ }^{11}$ and New Testaments. It is unlikely that beacon fire station was situated on western slopes, where mount itself will be an obstacle to further communicating of the signal. Moreover, it is reasonable to suggest that beacon fire station should be located close to watershed of Mount of Olives, rather than on its eastern slopes much lower and more distant from the city of Jerusalem. Therefore for presented here set of experiments location of the first station of beacon fire was suggested on the summit of the Mount of Olives, above the contour line of 800 meters.

There is no indication that any kind of specially constructed tall building or elevated platform was used for delivery of signal from Mount of Olives. If such a structure would exist in very vicinity of Jerusalem it was most likely mentioned by eyewitnesses ${ }^{12}$. However there is no reference as to existence of such erection on the Mount of Olives. So in our experiments we suggest that fire was set on the ground. However the total height of pile of wood and flame above it was usually estimated in experiments as 10 meters. As the DTM cells represent averaged elevation values, 10 meters height doesn't seem to be too exaggerated suggestion. In order to check vulnerability of results to the height of fire in some experiments 20 meters was used instead.

Since, from one hand, exact location of the first station of beacon fire on the significantly prolonged Mount of Olives is unknown, and from other hand, Horn of Sartaba' peak is relatively a small spot, it is more convenient to check which parts of Mount of Olives summit are visible from Horn of Sartaba. In all experiments an averaged value $(370 \mathrm{~m})$ of DTM cell was corrected by adding 7 meters in such a way that the resulted absolute height of Horn of Sartaba will be 377 meter above the Mediterranean Sea level. This value represents terrain surface of the mountain peak. Additionally in order to check how tallness of suggested tower

as the participation of the German and Italian space agencies. Together, this international space collaboration generates a near-global digital elevation model (DEM) of the Earth using radar interferometry. A description of the SRTM mission can be found in Farr et al. 2007

${ }^{10}$ Between, 1987 and 1993 at the Geological Survey of Israel (GSI) Dr. John Kendrick Hall (with a financial support provided by Dr. Richard L.W. Cleave) produced 25-m DTM in partnership with the Survey of Israel, which holds proprietary rights to the resulting DTM.

112 Sam. XV. 30, Neh. VIII. 15, Ezek. XI. 23, Zech. XIV. 4.

Pre-figuration theological approach allows to utilize New Testament references for localization as well

${ }^{12}$ Present day there are three tall towers on the Mount of Olives: water tower $(55 \mathrm{~m})$ named after Ya'akov Sourasky at the Hebrew University campus, Church of the Ascension belfry $(\sim 50 \mathrm{~m})$ in the Augusta Victoria hospital, and bell tower $(64 \mathrm{~m})$ in the Mount of Olives Convent of the Ascension of Our Lord. However despite their considerable height, neither one of them is visible from Horn of Sartaba. 
on the summit will influence results of visibility analysis special adjustments were introduced in each experiment in accordance with hypothesis under verification.

\section{DIRECT - CISJRD EXPERIMENTS}

Till today remains of Alexandrion walls still stand for a height of several meters. It is not weird therefore to suggest that at least part of towers on Horn of Sartaba were as tall as $10 \mathrm{~m}$, similarly to the height of present-day walls of the Old City of Jerusalem. Results of visibility analysis were negative, i.e. there were no line of sight between $10 \mathrm{~m}$ high pile of fire on the Mount of Olives and observer on the suggested $10 \mathrm{~m}$ high tower at the top of Horn of Sartaba (Fig. 3).

Fig. 3: Visibility from Horn of Sartaba $+10 \mathrm{~m}$ to Mt. of Olives $+10 \mathrm{~m}$

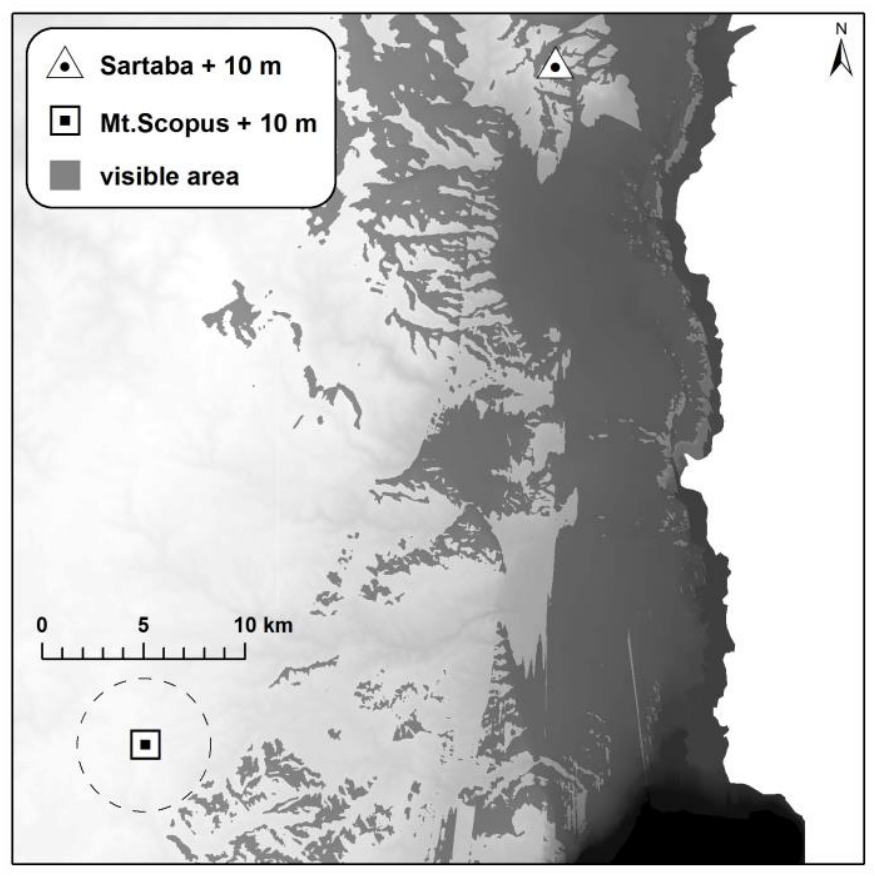

This result is not decisive of course, since one can argue that observer tower at the top of Horn of Sartaba was higher than 10 meters. But how tall this hypothetic tower could be? Describing Jerusalem defenses on the eve Roman siege, Josephus Flavius notices three extraordinary towers, constructed by Herod the Great "to the memory of those three persons who had been the dearest to him, and from whom he named them":

... Hippicus, so named from his friend... insomuch that the entire height added together amounted to fourscore cubits.

...The second tower, which he named from his brother Phasaelus... the entire altitude was about ninety cubits...

... The third tower was Mariamne, for that was his queen's name... The entire height of this 
Frumin M.: To Sartaba, from Sartaba" a new proposal to identify the location of the second station on the beacon line from Jerusalem to Babylon

tower was fifty cubits. ",13

Approximating cubit as $0.5 \mathrm{~m}$, we can roughly estimate height of Hippicus Tower as $40 \mathrm{~m}$, height of Phasaelus Tower as $45 \mathrm{~m}$, and Mariamne Tower - $25 \mathrm{~m}$. For experiment purposes however another famous contemporary tower described by Josephus Flavius was chosen to be modeled:

Psephinus tower elevated ... at the north-west corner for being seventy cubits high ${ }^{14} \ldots$ i.e. $35 \mathrm{~m}$ height parameter was used in calculating OFFSETA.

Results of visibility analysis were also negative, i.e. there were no line of sight between $10 \mathrm{~m}$ high pile of fire on the Mount of Olives and observer on the suggested $35 \mathrm{~m}$ high tower at the top of Horn of Sartaba. (Fig. 4).

Fig. 4: Visibility from Horn of Sartaba $+35 \mathrm{~m}$ to Mt. of Olives $+10 \mathrm{~m}$

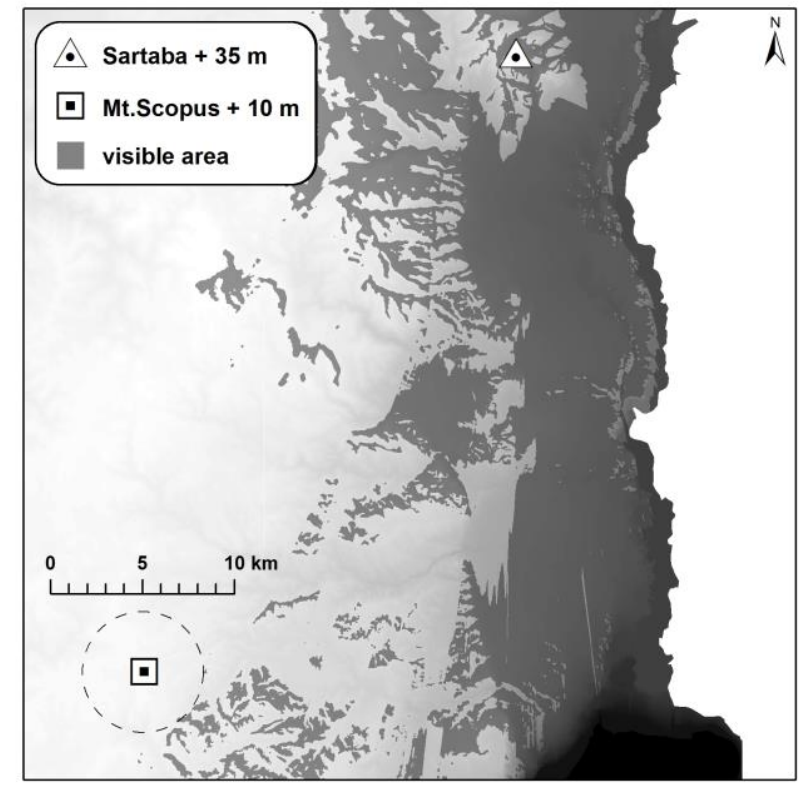

Looking at the amount of debris on the top of Horn of Sartaba it is difficult to assume the possibility of existence in the site of much higher building. However taking line of argumentation ad absurdum let's check how tall should be the building in order to establish the line of sight with the Mount of Olives.

The first Israeli skyscraper of new time, Migdal Shalom ${ }^{15}$ was opened at 1965 and it rises to $130 \mathrm{~m}$ height. However even in this case results of visibility analysis were negative, i.e. there were no line of sight between $10 \mathrm{~m}$ high pile of fire on the Mount of Olives and observer on top of the suggested $130 \mathrm{~m}$ high tower at the top of Horn of Sartaba.

\footnotetext{
13 The Wars of the Jews, Book V, Chapter IV. Quoted by Josephus, Flavius, 1895

${ }^{14}$ Ibid

15 Shalom Mayer Tower
} 
Tel Aviv Diamond Exchange / Moshe Aviv Tower - so called Bursa, is contemporary ${ }^{16}$ the highest building in Israel. Its height is 244 meters. If such a tall building was standing at the top of Horn of Sartaba it would be possible to see from its upper levels most of Mount of Olives. It is obvious however that such building was absolutely impossible to construct two thousand years ago.

In other words hypothesis that a broken line of sight between summit of Mount of Olives and Horn of Sartaba will be restored if only ruined tower of Alexandrion will be raised and refurbished proved by GIS model to be incorrect and should be ruled out completely.

Short summary of experiments is provided in the Table. 2

Table 2: Direct - CisJrd experiments

\begin{tabular}{|l|c|c|c|c|c|c|l|}
\hline \multicolumn{1}{|c|}{ Exp: eriment } & $\begin{array}{c}\text { Observer } \\
\text { Point }\end{array}$ & $\begin{array}{c}\text { DTM } \\
\text { correction }\end{array}$ & $\begin{array}{c}\text { Tallness } \\
\text { in check }\end{array}$ & ${\text { Offset } \mathbf{A}^{\mathbf{1 7}}}$ & ${\text { Offset } \mathbf{B}^{\mathbf{1 8}}}^{\text {Visible }}$ & \multicolumn{1}{|l|}{ Imitated building } \\
\hline HS_010_MtO_10 & Horn of Sartaba & $7 \mathrm{~m}$ & $10 \mathrm{~m}$ & $17 \mathrm{~m}$ & $10 \mathrm{~m}$ & No & Jerusalem walls \\
\hline HS_010_MtO_20 & Horn of Sartaba & $7 \mathrm{~m}$ & $10 \mathrm{~m}$ & $17 \mathrm{~m}$ & $20 \mathrm{~m}$ & No & Jerusalem walls \\
\hline HS_035_MtO_10 & Horn of Sartaba & $7 \mathrm{~m}$ & $35 \mathrm{~m}$ & $42 \mathrm{~m}$ & $10 \mathrm{~m}$ & No & Psephina Tower \\
\hline HS_130_MtO_10 & Horn of Sartaba & $7 \mathrm{~m}$ & $130 \mathrm{~m}$ & $137 \mathrm{~m}$ & $10 \mathrm{~m}$ & No & Migdal Shalom Tower \\
\hline HS_244_MtO_10 & Horn of Sartaba & $7 \mathrm{~m}$ & $244 \mathrm{~m}$ & $251 \mathrm{~m}$ & $10 \mathrm{~m}$ & Yes & Moshe Aviv Tower \\
\hline
\end{tabular}

\section{DIRECT - TRANSJRD EXPERIMENTS}

In order to check technical aspects of proposed by Meir Ben Dov localization two experiments were conducted. In one of them the place of beacon fire station was set at present day Mount Scopus campus of the Hebrew University and height of pile of wood and flame above it was suggested to be 10 meters. In other experiment beacon fire station was set at the present day Augusta Victoria hospital site. In both cases height of suggested observer tower in 'Iraq al-Amir area was approximated as $35 \mathrm{~m}$ - as Psephina according to Flavius. However in both cases there results of visibility analysis were negative. Although extensive areas on the western slopes of central Transjordan plateau across the Jordan Valley are clearly visible, both well-known 'Iraq al-Amir and Qasr al-Abd historic sites, associated with Tobiah's family are situated in narrow valley along Wadi es-Seer ${ }^{20}$ and therefore there is no line of sight between their location and summit of Mount of Olives (Fig. 5).

${ }^{16}$ Until forthcoming completion of the construction works at Azrieli Sarona Tower $(\sim 255 \mathrm{~m})$

${ }^{17}$ In these experiments OFFSETA represents total height to be added to the averaged value of DTM cell and consists of constant 7 meter correction value - in order to obtain actual height of Horn of Sartaba peak - and changing parameter of imitated structure tallness.

${ }^{18}$ In these experiments OFFSETB represents height of lighten beacon fire above the surface level of Mount of Olives

${ }^{19}$ This experiment was carried out in order to make sure that inaccuracy of DTM does not influence results of visibility analysis in crucial case. In this experiment height of beacon fire at Mount of Olives was raised to $20 \mathrm{~m}$, while height of observer tower at Horn of Sartaba assumed to be 10 meters. However visibility analysis results were negative as in the previous experiment

${ }^{20}$ According to archeological data not only these two well-known sites, but Tobiah's settlement in the region were restricted mainly to a narrow valley along Wadi es-Seer, the Wadi Kafrein, and the immediate vicinity of 'Iraq al-Amir, isolated from its neighbors in the Transjordan plateau. See: Ji, 1998. 
Fig. 5: Visibility from Mount of Olives $+10 \mathrm{~m}$ to Wadi es-Seer $+35 \mathrm{~m}$

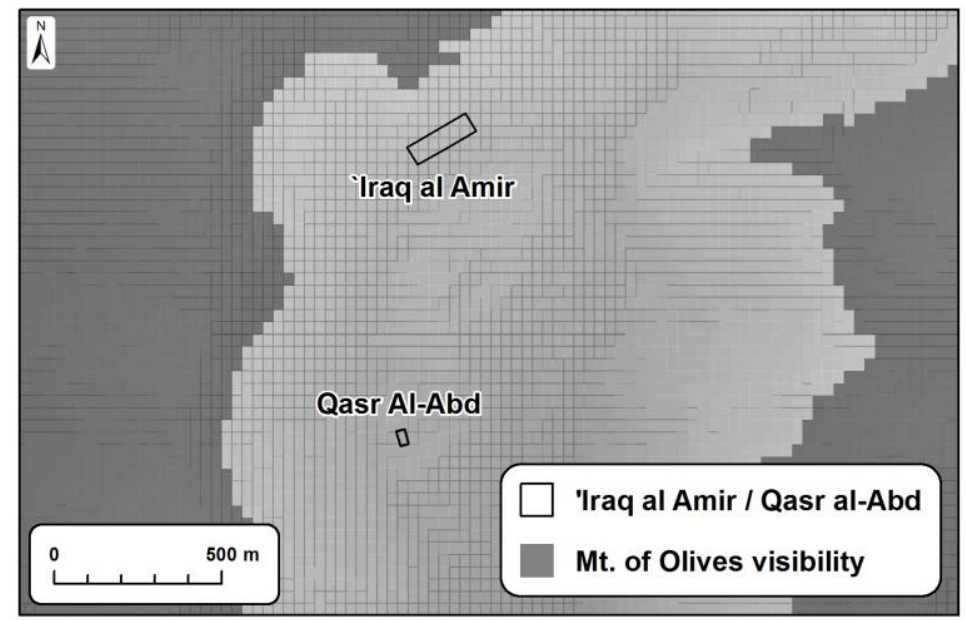

\section{IN-BETWEEN CONCEPT}

Attempt to solve the existed discrepancy between Mishnah description of communication chain of beacon fire station and absence of direct line of sight between summit of Mount of Olives and Horn of Sartaba led many to suggest that the provided list of stations is not complete and name only key stations, while there were many more ${ }^{21}$. Close examination of such proposition however raises several questions.

All suggested places were supposed to be manned at least once per month for few days in order to lite beacon fire at the proper time. So these sites should be easy accessible, provided with water and food for personnel and wood for fire. If centrally established by authorities for explicit purposes such chain of semi-permanent outposts was supposed to have certain degree of standardization. However nothing similar to such a network was ever found or described in historic sources. On other hand there is no need in numerous intermediate stations. In fact only one station visible from both Mount of Olives and Horn of Sartaba is necessary. There are plenty of such sites, along the road from Jerusalem to the Dead Sea alone. $^{22}$ But if there was only one additional station in-between why to omit its name from the list?

\section{SPLITTED RECEIVER - TRANSMITTER PROPOSITION}

Interesting phenomena was revealed during conduction of visibility analysis between Horn of Sartaba and Mount of Olives. While at least two mountain ridges prevent line of sight between the topmost parts of these two regions (Fig. 6), considerable lowland areas in the Jordan Valley have a direct view of Mount of Olives from surface level. Some of these areas are situated in foot of Horn of Sartaba and are visible from its peak as well (Figs. 7-8).

\footnotetext{
${ }^{21}$ Rosenson, 1983

${ }^{22}$ For instance, Castrum Rouge site in vicinity of Good Samaritan Museum.
} 
Fig. 6: Line of Sight Visibility Profile from Mt. of Olives to Horn of Sartaba

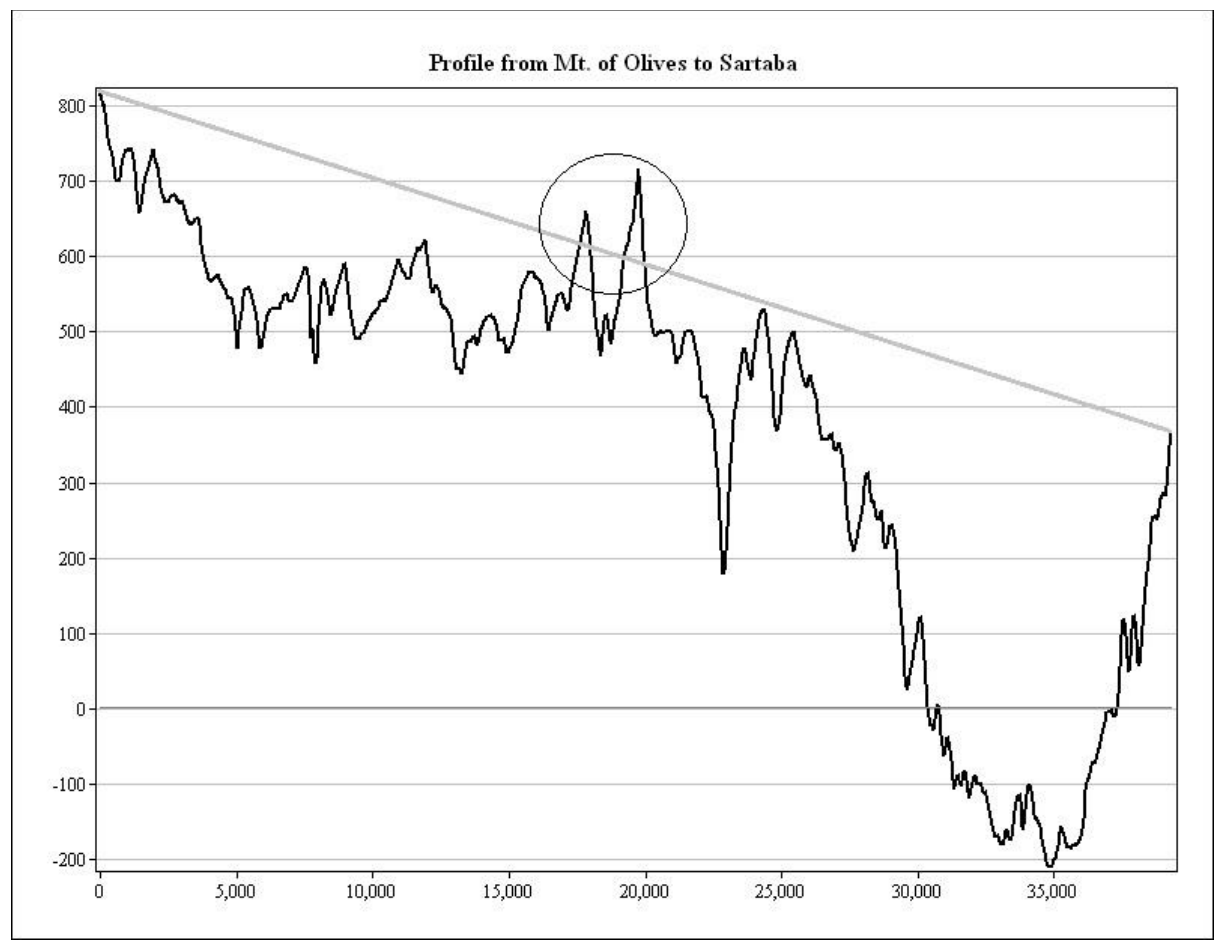

Fig. 7: Visibility from Mt. of Olives $+10 \mathrm{~m}$ to Horn of Sartaba vicinity

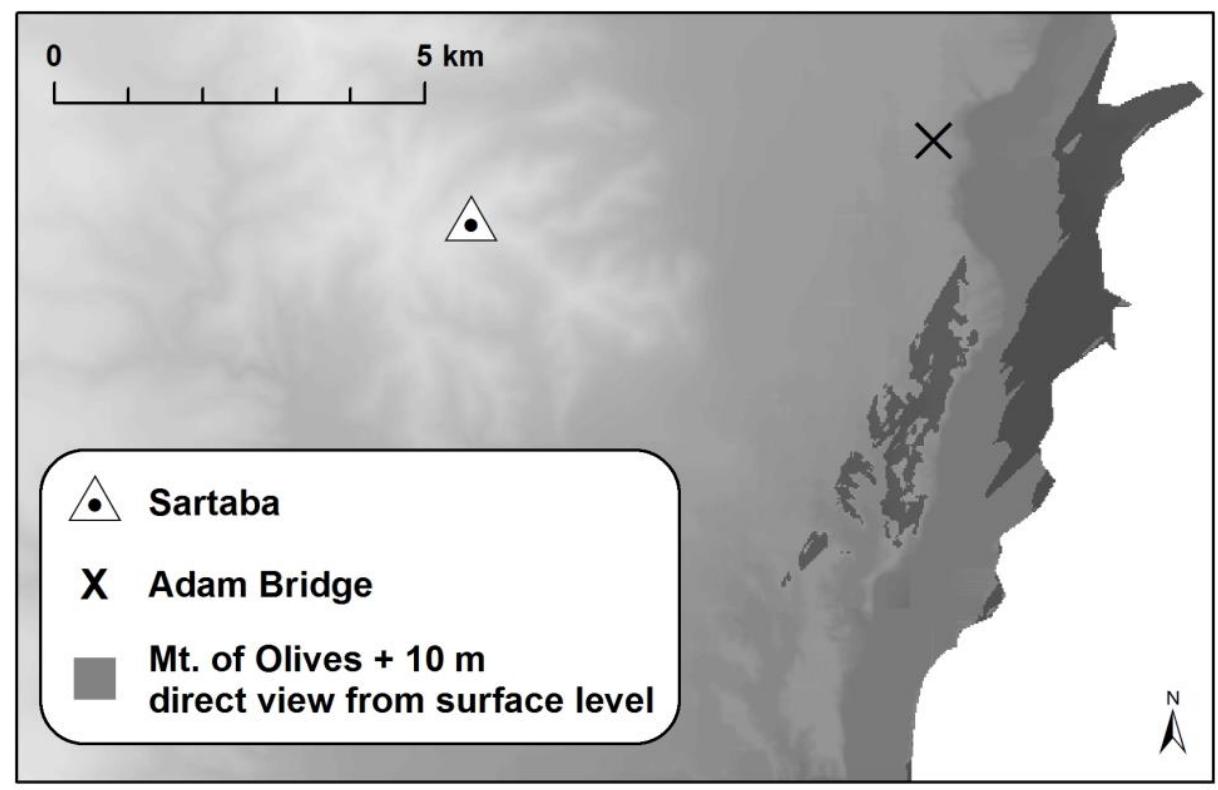


Frumin M.: To Sartaba, from Sartaba" a new proposal to identify the location of the second station on the beacon line from Jerusalem to Babylon

Fig. 8: Superimposed results of visibility analysis for Mt. of Olives $+10 \mathrm{~m}$ and Horn of Sartaba $+10 \mathrm{~m}$

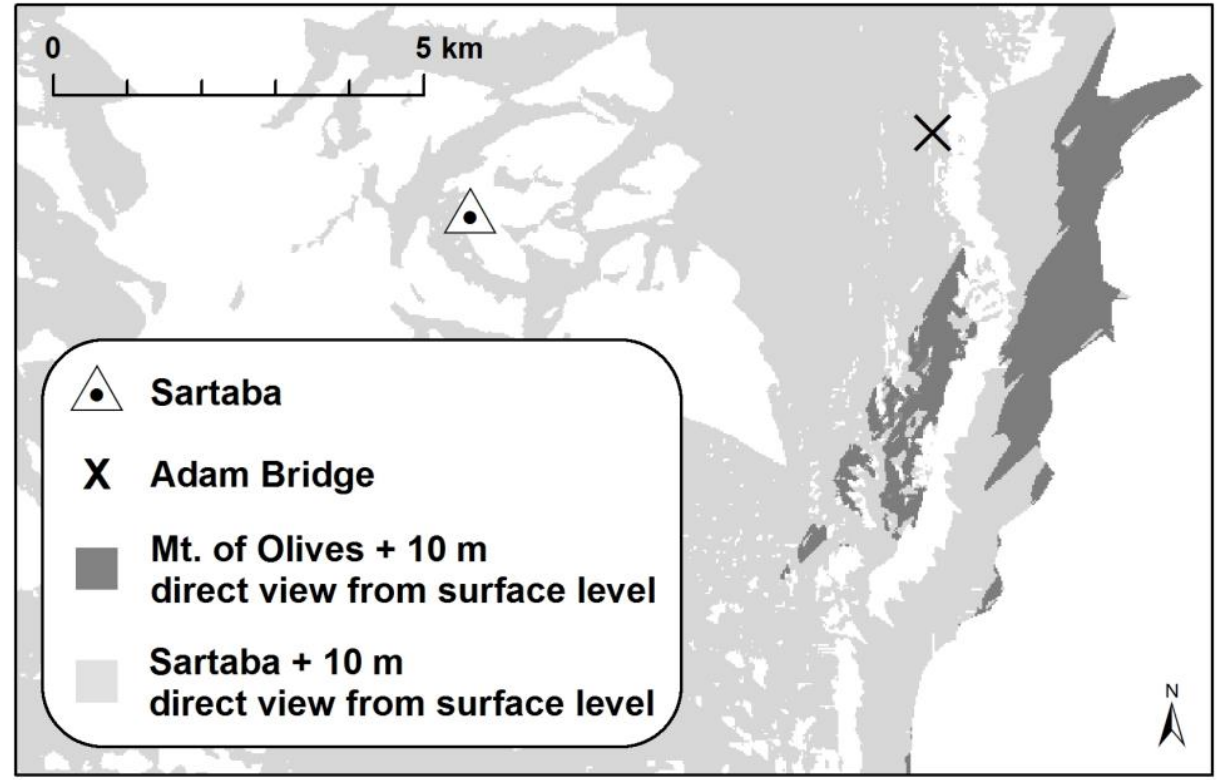

This provides a basis for a new proposition of Sartaba station splitted for two: beacon fire signal was conducted from Mount of Olives to the foot of Horn of Sartaba, where provisional nightly watch was placed. It was impossible to conduct the signal further north from this low point, of course; however task of this sentry was much more modest. On receiving the signal from Jerusalem the observers were supposed to indicate its recognition to the Horn of Sartaba where "transmitting" station with long before prepared pile of wood was ready. Due to the closeness between two places it was enough to light a small torch held by hand. On indication from below beacon fire on the top of Horn of Sartaba was ignited and the signal was conducted further to Grofina. The whole procedure was apparently not slowing down the conduction of signal for more than quarter of hour. As the low "receiving" station didn't need any special setting up on the spot and could easily be operated from Sartaba by patrols, it is not surprising that it was not mentioned specifically among other stations. Both receiver and transmitter parts of the second station were undoubtedly connected for Mishnah text compiler to the same distinguished regional geographical entity - Horn of Sartaba mountain peak.

\section{CONCLUSIONS}

Set of tests for examination of direct line of sight theory was conducted. Performed visibility analysis proved that neither one of existing alternatives of Direct concept is not reliable:

Direct - CisJrd - No building, which could be constructed two thousand years ago at the top of Horn of Sartaba, would be tall enough to see from it Mount of Olives 
Direct - TransJrd - There is no visibility between Mount of Olives summit and Tobiah's family well-known sites across the Jordan Valley

However the results of the visibility analysis provide a background for a new suggestion. It is possible that the primary receiving and subsequent conveyance of the signal were done not at the same point but in two separated places on Horn of Sartaba mountain with eye contact between them. According to the visibility analysis there is an area at the foot of the Horn of Sartaba with a proper line of sight to the Mount of Olives. Apparently there was situated a receiving place. After that, from the top of the Horn of Sartaba, the signal was conveyed to Grofina, the next stop in the chain of beacon fires.

Visibility analysis methods of geographic information systems provide useful and indispensable tools for historical geographical studies and make their way to archaeological research as well. Improvement of digital terrain models quality in recent years make results of visibility analysis more accurate and reliable. Carrying out of visibility analysis meaningfully enrich our understanding of environment and certainly should be a part of recommended routine for landscape archaeology inquiries.

\section{REFERENCES}

Abel, F.-M. (1933). Géographie de la Palestine: Géographie physique et historique. Paris: Librairie Lecoffre J.Gabalda et Cie.

Ben-Dov, M. (1982). "From Sartaba to Grofina" - A New Suggestion for the Location of Sartaba" (Hebrew). Cathedra, vol. 23: 11-16.

Conder, C. R. and H. H. Kitchener (1882). The Survey of Western Palestine: memoirs of the topography, orography, hydrography, and archaeology, volume II (Samaria), London: The Palestine Exploration Fund.

Farr, T. G., P. A. Rosen, E. Caro, R. Crippen, R. Duren, S. Hensley, M. Kobrick, M. Paller, E. Rodriguez, L. Roth, D. Seal, S. Shaffer, J. Shimada, J. Umland, M. Werner, M. Oskin, D. Burbank and D. Alsdorf (2007). The Shuttle Radar Topography Mission. Reviews of Geophysics, vol. 45, issue 2 (June).

Hall, J. K. (2008). "The 25-m DTM (Digital Terrain Model) of Israel". Israel Journal of Earth Sciences 57(3): 145-147.

Irsai, O. (1982). "Nevertheless, Sartaba is Alexandrion" (Hebrew), Cathedra, vol.25: 169-171.

Ji, C. C. (1998). A New Look at the Tobiads in 'Iraq al-Amir. Liber Annuus 48: 417- 40.

Josephus, Flavius (1895). The Works of Flavius Josephus (JOE). Translated by William Whiston. Auburn and Buffalo, NY: John E. Beardsley, BibleWorks, vol. 7.

Obermeyer, J. (1929). Die Landschaft Babylonien im Zeitalter des Talmuds und des Gaonats: Geographie und Geschichte nach talmudischen, arabischen und andern Quellen. Frankfurt am Main: J. Kauffmann

Robinson, E. (1857). Later biblical researches in Palestine and in the adjacent regions. Boston: Crocker and Brewster.

Rosenson, I. (1983). Kindling the beacons of the new moon: the route from Jerusalem to Sartaba (Hebrew), Cathedra, vol. 27: 175-179.

Tsafrir, Y. and Magen, Y. (1984). "Two Seasons of Excavations at the Sartaba / Alexandrium Fortress" (Hebrew). Qadmoniot, no. 1(65): 26-32. 